\title{
THE APPLICATION OF THE PLACKETT-BURMAN DESIGN IN INVESTIGATING ACE INHIBITORY PEPTIDE-PRODUCING CONDITIONS AND MEDIA FOR LACTOBACILLUS BULGARICUS LB6
}

\author{
Xiaoyu Shi ${ }^{1 凶}$, Chen $\mathrm{He}^{1}$, Jiangpeng Meng ${ }^{2}$, Ni Xin² ${ }^{2}$ Zhe $\mathrm{Ji}^{1}$ \\ ${ }^{1}$ School of Food and Biological Engineering, Shaanxi University of Science and Technology \\ Xi'an, 710021, China \\ ${ }^{2}$ Xi'an Baiyue Goat's Milk Corp. \\ Xi'an, 710089, China
}

\begin{abstract}
Background. The intake of angiotensin converting enzyme (ACE, EC 3.4.15.1) inhibitory peptides from food has become a promising method for treating hypertension. Lactic acid producing bacteria are widely used to produce ACE inhibitors during fermentation.

Material and methods. Several factors which promote the production of ACE inhibitory peptides in Lactobacillus bulgaricus LB6 (inoculum size, incubation temperature, goat's milk powder, sterilization time, whey powder, casein hydrolyses and calcium lactate) and media (casein peptone, soybean peptone, glucose, casein, ascorbic acid, $\mathrm{Ca}\left(\mathrm{H}_{2} \mathrm{PO}_{4}\right)_{2}$ and lactose) were investigated to optimize and increase ACE inhibitory activity during the fermentation of goat's milk by using a Plackett-Burman design, in accordance with previous tests. Results. The results indicated that incubation temperature, whey powder, calcium lactate, soybean peptone, glucose and casein had significant effects on both ACE inhibition rate and viable counts. In addition, the effects of incubation temperature, whey powder, calcium lactate and glucose were found to increase ACE inhibition rate, while soybean peptone and casein caused it to decrease.

Conclusion. This investigation of conditions which promote the production of ACE inhibitory peptides and media for LB6 was performed using a Plackett-Burman design. The results indicated that incubation temperature, whey powder, calcium lactate, soybean peptone, glucose and casein had a significant impact on the ACE inhibition rate and viable counts of LB6, which provide the basis and reference for further optimization.
\end{abstract}

Keywords: Lactobacillus bulgaricus, ACE inhibitory peptides, goat's milk powder, Plackett-Burman design

\section{INTRODUCTION}

Hypertension is a major risk factor for chronic kidney disease, myocardial infarction, stroke, aneurysm, arteriosclerosis, renal disease and peripheral arterial disease, and may also lead to heart failure (Duprez et al., 2002; James et al., 2014; Macmahon et al., 1990). Six categories of drugs (diuretics, calcium channel

The work was partly supported by the Science and Technology Planning of Shaanxi Province (no. 2016KTZDNY02-08) and Shaanxi Innovation and Transformation Project of Agricultural Science and Technology (no. NYKJ-2015-004). 
blockers, angiotensin II receptor blockers, ACE inhibitors, $\alpha$-adrenergic antagonist and $\beta$-blockers) are employed to reduce hypertension (Grandi et al., 1996). ACE inhibitors are the most beneficial, as they protect the target organ without adverse effects on the metabolism of glycolipids.

ACE, also known as Kinase II, is a metalloproteinase containing two zinc-catalytically active sites (Cushman and Cheung, 1971), which can raise blood pressure by converting angiotensin-I to angiotensin-II (Leclerc et al., 2002; Nakamura et al., 1996; Ondetti et al., 1977; Pihlanto-Leppala, et al., 2001; Skeggs et al., 1956). ACE inhibitors can inhibit ACE activity. As side effects, such as dry-cough, pruritic rash and taste disorders, occur when using synthetic ACE inhibitors (Abassi et al., 2009; Tenenbaum et al., 2000), it is necessary to study food-derived ACE inhibitory peptides to produce antihypertensive products without toxic side effects. ACE inhibitory peptides can be tightly integrated with ACE in the human body, and it is not easy to release from the ACE binding area (Ondetti and Cushman, 1982). Thus, ACE inhibitory peptides can be used against hypertension.

Milk protein is a source of ACE inhibitory peptides from an animal source (Hernandezledesma et al., 2002; Maruyama, et al., 2006). Goat's milk has an unparalleled advantage compared to other dairy products. The protein, fat, minerals, vitamins and other nutrients present in goat's milk are more abundant than in other milks (Belewu and Aiyegbusi, 2002; Lópezaliaga et al., 2010; Park et al., 2007). Moreover, goat's milk contains smaller protein particles, composed of short-peptide fatty acids. Goat's milk is more similar to breast milk than other forms of dairy, and even has a higher level of immunoglobulin than breast milk (Haenlein, 2004). Lactic acid bacteria are a group of gram-positive bacteria that translate carbohydrates into lactic acid, which have been widely used in food fermentation. Proteins are hydrolyzed into several bioactive peptides with health-promoting functions by lactic acid bacteria during incubation. There are 70 kinds of ACE inhibitory peptides from goat's milk in the AHTPDB (Kumar et al., 2015). Parmar et al. (2017) identified and characterized 26 peptides with ACE inhibitory activity in fermented goat's milk with Lactobacillus casei NK9 and Lactobacillus fermentum LF.
In our previous study, 4 strains, including L. bulgaricus, Lactobacillus rhamnosus, Lactobacillus helveticus and Lactobacillus reuteri were selected as starter cultures for ACE inhibitory peptide production out of 28 probiotic Lactobacillus strains (Chen et al., 2012). The effects of ACE inhibitory peptide-producing conditions and media of L. bulgaricus LB6 on the ACE inhibition rate and viable counts in fermented goat's milk were performed by single factor experiments (Shu et al., 2013a; 2013b; 2014). The aim of this study was to investigate the significant factors for incubation conditions and media of L. bulgaricus LB6, to maximize ACE inhibitory activity and viable counts of LB6 during fermentation, using the Plackett-Burman design based on previous studies, which provided a reference for further optimization.

\section{MATERIAL AND METHODS}

Strain. L. bulgaricus LB6 was provided by the college of Food and Biological Engineering, Shaanxi University of Science and Technology (Xi'an, China). The starter cultures were stored at $-20^{\circ} \mathrm{C}$ in freeze-dried powder. L. bulgaricus LB6 was activated three times in rehydrated Man Rogosa Sharpe broth (MRS, Hopebio, Qindao, China) with an inoculum size of $5 \%$ at $37^{\circ} \mathrm{C}$ for $24 \mathrm{~h}$ prior to use as starter culture to ferment goat's milk.

Preparation of fermented goat's milk. A starter culture containing L. bulgaricus LB6 was inoculated into pasteurized reconstituted skimmed goat's milk, with an inoculum size of $5 \%$, and fermented at $37^{\circ} \mathrm{C}$ for $12 \mathrm{~h}$.

Determination of ACE inhibitory activity. The whey fraction from fermented goat's milk was used to measure ACE inhibitory activity. Aliquots of the fermented goat's milk were collected, vigorously stirred and centrifuged at $5000 \times \mathrm{g}$ for $15 \mathrm{~min}$ to obtain the corresponding whey fractions. The supernatants collected were filtered through a Xinhua filter and used to determine their ACE inhibitory activity. ACE inhibitory activity was measured by a spectrophotometric assay, according to the method of Cushman and Cheung (1971) with modifications. $80 \mu \mathrm{L}$ of each sample was added to $200 \mu \mathrm{L}$ sodium borate buffer $\left(0.1 \mathrm{~mol} \cdot \mathrm{L}^{-1}\right.$, 
Shi, X., He, Ch., Meng, J., Xin, N., Ji, Z. (2018). The application of the Plackett-Burman design in investigating ACE inhibitory peptide-producing conditions and media for Lactobacillus bulgaricus LB6. Acta Sci. Pol. Technol. Aliment., 17(2), 125-132. http:// dx.doi.org/10.17306/J.AFS.2018.0536

$\mathrm{pH}$ 8.3) containing $\mathrm{NaCl}\left(0.30 \mathrm{~mol} \cdot \mathrm{L}^{-1}\right)$ and $\mathrm{HHL}$ $\left(5 \mathrm{mmol} \cdot \mathrm{L}^{-1}\right)$. ACE $\left(20 \mu \mathrm{L}, 0.1 \mathrm{UmL}^{-1}\right)$ was added. The reaction mixture was then incubated at $37^{\circ} \mathrm{C}$ for $30 \min .250 \mu \mathrm{L} 1 \mathrm{~mol} \cdot \mathrm{L}^{-1} \mathrm{HCl}$ was added to terminate the reaction. The hippuric acid formed was extracted by $1.7 \mathrm{~mL}$ ethyl acetate and evaporated at $120^{\circ} \mathrm{C}$ for $30 \mathrm{~min}$. It was then dissolved in $2 \mathrm{~mL}$ deionized water, after cooling to room temperature. The absorbance at $228 \mathrm{~nm}$ was measured in triplicate using UV-spectrophotometer (Shanghai Spectrum Instruments Co., Ltd, Shanghai, China).

Calculation of the ACE inhibition rate. The ACE inhibition rate was determined by the equation:

ACE inhibition rate, $\%=(A-B) /(A-C) \times 100 \%$

where:

$A$ - the optical density without the whey fraction,

$B$ - the optical density without ACE,

$C$-the optical density in the presence of both ACE and the whey fraction.

Measurement of viable counts. Fermented goat's milk was serially diluted in saline solution $(0.9 \%, \mathrm{w} / \mathrm{v}$, $\mathrm{NaCl}$ ) containing $0.1 \mathrm{~g} \cdot \mathrm{L}^{-1}$ peptone $(0.9 \%, \mathrm{w} / \mathrm{v}, \mathrm{NaCl})$ and spread on MRS agar plates. After dilution in triplicate, the mixture was incubated for $48 \mathrm{~h}$ at $37^{\circ} \mathrm{C}$. The results were expressed as colony forming units per milliliter [cfu $\left.\cdot \mathrm{mL}^{-1}\right]$ of fermented milk by manual counting.

Plackett-Burman design. The Plackett-Burman design is a two-level statistical test method, which quickly analyzes which of a range of factors have the most significant effect on the test result. It can also accurately exclude factors which are irrelevant or have negligible impact on the results. The Plackett-Burman design was used to determine significant factors on both $\mathrm{ACE}$ inhibition rate and viable counts of LB6. The test examined 10 factors; inoculum size, incubation temperature, goat's milk powder (Xi'an Baiyue Goat Milk Corp., Xi' an, China), sterilization time, whey powder (Xi'an Baiyue Goat Milk Corp., Xi' an, China), casein hydrolyses (Yobios., Xi'an, China), calcium lactate (Yobios., Xi'an, China) and three error terms, at two levels (a higher level coded as +1 , a lower level coded as -1 ) and was designed to examine ACE inhibitory
Table 1. The factor level coding table of Box-Behnken for ACE inhibitory peptide-producing conditions of LB6

\begin{tabular}{clcc}
\hline \multirow{2}{*}{ Variables } & \multicolumn{1}{c}{ Factor } & $\begin{array}{c}\text { Lower } \\
\text { level }\end{array}$ & $\begin{array}{c}\text { Higher } \\
\text { level }\end{array}$ \\
\cline { 3 - 4 } & & $(-1)$ & $(+1)$ \\
\hline$X 1$ & inoculum size, \% & 4.8 & 6 \\
$X 3$ & incubation temperature, ${ }^{\circ} \mathrm{C}$ & 30 & 37 \\
$X 5$ & goat's milk powder, \% & 11.2 & 14 \\
$X 7$ & sterilization time, min & 16 & 20 \\
$X 8$ & whey powder, \% & 0.6 & 0.8 \\
$X 9$ & casein hydrolyses, \% & 0.4 & 0.5 \\
$X 10$ & calcium lactate, \% & 0.4 & 0.5 \\
\hline
\end{tabular}

peptide-producing conditions (Table 1). The design contained 11 factors; casein peptone (Aobox Biotechnology, Beijing, China), soybean peptone (Aobox Biotechnology, Beijing, China), glucose (Yobios., Xi'an, China), casein (Aobox Biotechnology, Beijing, China), ascorbic acid (Yobios., Xi'an, China), $\mathrm{Ca}\left(\mathrm{H}_{2} \mathrm{PO}_{4}\right)_{2}$ (Yobios., Xi'an, China), lactose (Yobios., Xi'an, China), $\mathrm{KH}_{2} \mathrm{PO}_{4}$ (Yobios., Xi'an, China) and three error terms, spanning 12 runs at two levels to examine ACE inhibitory peptide-producing media (Table 2).

Table 2. The coding table of Plackett-Burman for ACE inhibitory peptide-producing media of LB6

\begin{tabular}{clcc}
\hline Variables & \multicolumn{1}{c}{$\begin{array}{c}\text { Factor } \\
\%\end{array}$} & $\begin{array}{c}\text { Lower } \\
\text { level }\end{array}$ & $\begin{array}{c}\text { Higher } \\
\text { level }\end{array}$ \\
\cline { 3 - 4 } & & $(-1)$ & $(+1)$ \\
\hline$X 1$ & casein peptone & 0.72 & 0.90 \\
$X 3$ & soybean peptone & 0.4 & 0.5 \\
$X 4$ & glucose & 0.72 & 0.90 \\
$X 5$ & casein & 0.16 & 0.20 \\
$X 7$ & ascorbic acid & 0.02 & 0.03 \\
$X 8$ & Ca( $\left.\mathrm{H}_{2} \mathrm{PO}_{4}\right)_{2}$ & 0.02 & 0.03 \\
$X 10$ & lactose & 0.56 & 0.70 \\
$X 11$ & $\mathrm{KH}_{2} \mathrm{PO}_{4}$ & 0.24 & 0.30 \\
\hline
\end{tabular}


Statistical analysis. SAS (Version, 12.0, SAS Institute Inc., Cary, NC, USA) was used for statistical analysis of the experimental data to identify the significant variables and corresponding coefficients. The coefficient, sum of squares $(S S \%)$, and confidence intervals $(C I)$ were evaluated to analyze the ACE inhibition rate and viable counts from each of the trials.

\section{RESULTS}

\section{Plackett-Burman investigation of ACE inhibitory peptide-producing conditions}

The design and the results of the investigation of ACE inhibitory peptide-producing conditions were shown in Table 3. $Y 1[\%]$ represented the ACE inhibition rate and $Y 2\left[\lg \left(\mathrm{cfu} \cdot \mathrm{mL}^{-1}\right)\right]$ represented viable counts of LB6. The effects of the ACE inhibitory peptide-producing conditions varied during fermentation, so the ACE inhibition rate and the number of viable cells of LB6 changed under different conditions.

As shown in Figure 1, three variables, incubation temperature $(X 3)$, whey powder $(X 8)$ and calcium lactate $(X 10)$ accounted for a large proportion of the percentage sum of squares on the Pareto chart. This indicated that the three variables had significant positive $\mathbf{a}$

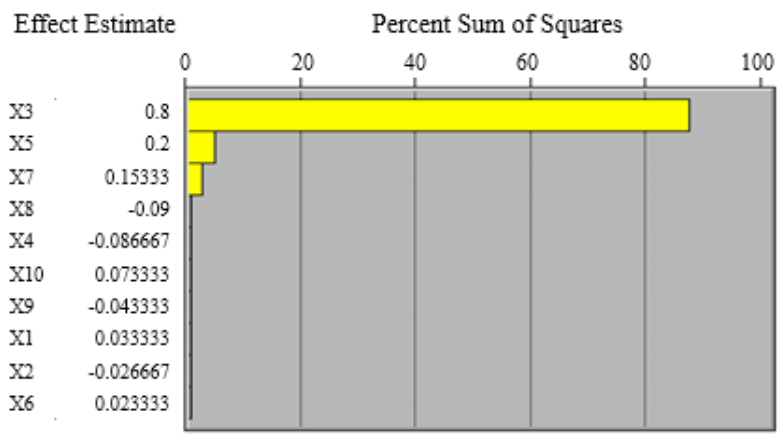

b

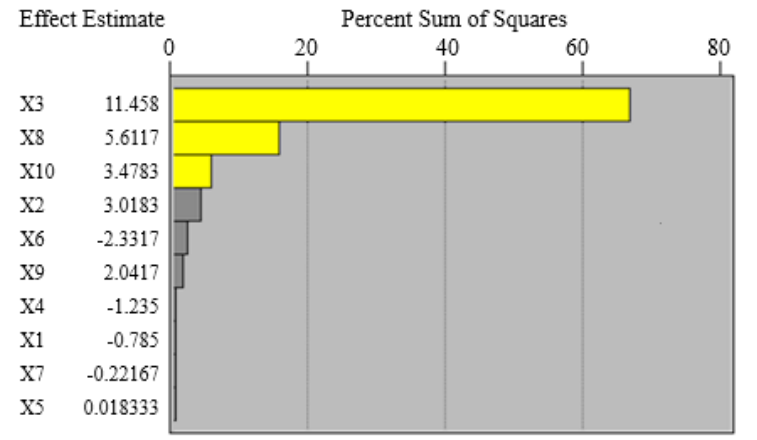

Fig. 1. The effects of factors on ACE inhibition rate (a) and viable counts of LB6 (b) for conditions of LB6

Table 3. The design and results of Plackett-Burman testing for ACE inhibitory peptide-producing conditions of LB6

\begin{tabular}{rrrrrrrrrrrrc}
\hline Run & $X 1$ & $X 2$ & $X 3$ & $X 4$ & $X 5$ & $X 6$ & $X 7$ & $X 8$ & $X 9$ & $X 10$ & $\begin{array}{c}Y 1 \\
\%\end{array}$ & $\begin{array}{c}Y 2 \\
\lg \left(\mathrm{cfu} \cdot \mathrm{mL}^{-1}\right)\end{array}$ \\
\hline 1 & 1 & -1 & 1 & -1 & -1 & -1 & 1 & 1 & 1 & -1 & 81.33 & 8.59 \\
2 & 1 & 1 & -1 & 1 & -1 & -1 & -1 & 1 & 1 & 1 & 78.57 & 7.71 \\
3 & -1 & 1 & 1 & -1 & 1 & -1 & -1 & -1 & 1 & 1 & 83.24 & 8.74 \\
4 & 1 & -1 & 1 & 1 & -1 & 1 & -1 & -1 & -1 & 1 & 73.81 & 8.58 \\
5 & 1 & 1 & -1 & 1 & 1 & -1 & 1 & -1 & -1 & -1 & 64.02 & 8.01 \\
6 & 1 & 1 & 1 & -1 & 1 & 1 & -1 & 1 & -1 & -1 & 83.43 & 8.79 \\
7 & -1 & 1 & 1 & 1 & -1 & 1 & 1 & -1 & 1 & -1 & 79.17 & 8.67 \\
8 & -1 & -1 & 1 & 1 & 1 & -1 & 1 & 1 & -1 & 1 & 85.55 & 8.90 \\
9 & -1 & -1 & -1 & 1 & 1 & 1 & -1 & 1 & 1 & -1 & 67.33 & 7.74 \\
10 & 1 & -1 & -1 & -1 & 1 & 1 & 1 & -1 & 1 & 1 & 68.64 & 8.29 \\
11 & -1 & 1 & -1 & -1 & -1 & 1 & 1 & 1 & -1 & 1 & 72.78 & 7.87 \\
12 & -1 & -1 & -1 & -1 & -1 & -1 & -1 & -1 & -1 & -1 & 66.44 & 7.85 \\
\hline
\end{tabular}


Shi, X., He, Ch., Meng, J., Xin, N., Ji, Z. (2018). The application of the Plackett-Burman design in investigating ACE inhibitory peptide-producing conditions and media for Lactobacillus bulgaricus LB6. Acta Sci. Pol. Technol. Aliment., 17(2), 125-132. http:// dx.doi.org/10.17306/J.AFS.2018.0536

effects on the ACE inhibition rate (Fig. 2). The relative importance of the variables on viable counts was

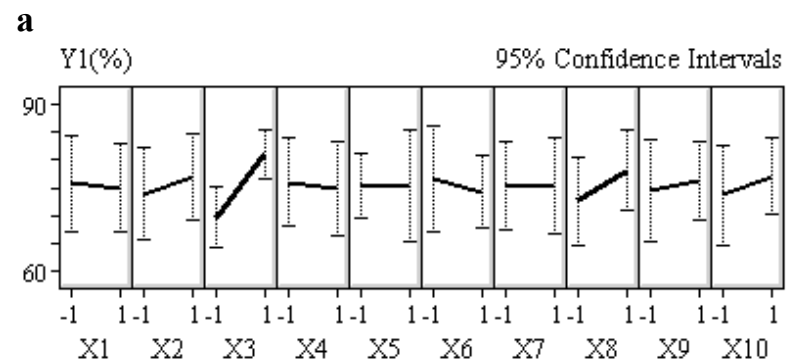

b

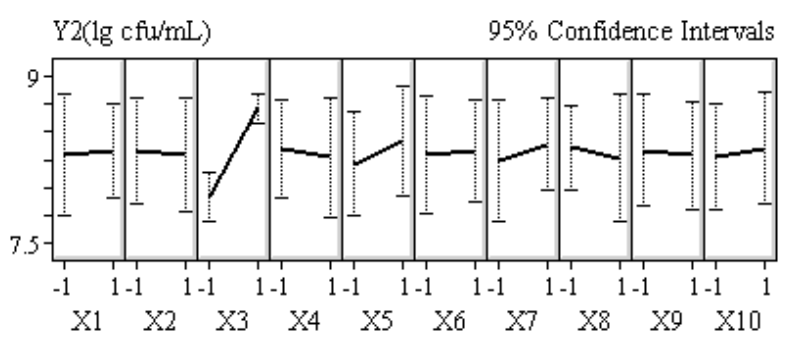

Fig. 2. The confidence interval of selected factors of ACE inhibitory peptide-producing conditions, regarding ACE inhibition rate (a) and viable counts of LB6 (b) found in Figure 1 as follows: $X 3>X 5>X 7>X 8>$ $X 10>X 9>X 1$. Since the focus of this study was ACE inhibition rate, the three most significant factors, incubation temperature, whey powder and calcium lactate, were selected for subsequent testing.

\section{Plackett-Burman investigation of ACE inhibitory peptide-producing media}

The design and results of ACE inhibitory peptide-producing media were shown in Table 4. The ACE inhibition rate was represented by $Y 1$ [\%] and viable counts of LB6 was represented by $Y 2\left[\lg \left(\mathrm{cfu} \cdot \mathrm{mL}^{-1}\right)\right]$. All of the factors had different effects on the cells, so ACE inhibition rate and viable counts of LB6 changed when the media were changed.

The relative importance of the variables on $\mathrm{ACE}$ inhibition rate was found according to Figure 3 , as follows: $X 3>X 4>X 5>X 1>X 8>X 7>X 10>X 11$. The main factors of ACE inhibitory peptides were soybean peptone $(X 3)$, glucose $(X 4)$, casein $(X 5)$, in which the effects of soybean peptone and casein on ACE inhibition rate were negative and effect of glucose was positive (Fig. 4). The effects of factors on viable counts of LB6 for media were shown in Figure 3 as follows: $X 1>X 5>X 11>X 3>X 10>X 8>X 4>X 7$. The main

Table 4. The design and results of Plackett-Burman for ACE inhibitory peptide-producing media of LB6

\begin{tabular}{rrrrrrrrrrrrrrr}
\hline Run & $X 1$ & $X 2$ & $X 3$ & $X 4$ & $X 5$ & $X 6$ & $X 7$ & $X 8$ & $X 9$ & $X 10$ & $X 11$ & $\begin{array}{c}Y 1 \\
\%\end{array}$ & $\begin{array}{c}Y 2 \\
\lg \left(\mathrm{cfu} \cdot \mathrm{mL}^{-1}\right)\end{array}$ \\
\hline 1 & 1 & -1 & 1 & -1 & -1 & -1 & 1 & 1 & 1 & -1 & 1 & 87.50 & 8.02 \\
2 & 1 & 1 & -1 & 1 & -1 & -1 & -1 & 1 & 1 & 1 & -1 & 98.08 & 8.05 & 7.90 \\
3 & -1 & 1 & 1 & -1 & 1 & -1 & -1 & -1 & 1 & 1 & 1 & 78.79 & -1 & -1 \\
4 & 1 & -1 & 1 & 1 & -1 & 1 & -1 & -1 & -1 & 1 & 1 & 83.93 & 8.10 \\
5 & 1 & 1 & -1 & 1 & 1 & -1 & 1 & -1 & -1 & -1 & 1 & 86.21 & 7.98 \\
6 & 1 & 1 & 1 & -1 & 1 & 1 & -1 & 1 & -1 & -1 & -1 & 67.80 & 8.09 \\
7 & -1 & 1 & 1 & 1 & -1 & 1 & 1 & -1 & 1 & -1 & -1 & 90.20 & 8.14 \\
8 & -1 & -1 & 1 & 1 & 1 & -1 & 1 & 1 & -1 & 1 & -1 & 75.00 & 7.88 \\
9 & -1 & -1 & -1 & 1 & 1 & 1 & -1 & 1 & 1 & -1 & 1 & 92.00 & 7.96 \\
10 & 1 & -1 & -1 & -1 & 1 & 1 & 1 & -1 & 1 & 1 & -1 & 90.38 & 8.05 \\
11 & -1 & 1 & -1 & -1 & -1 & 1 & 1 & 1 & -1 & 1 & 1 & 79.25 & 7.97 \\
12 & -1 & -1 & -1 & -1 & -1 & -1 & -1 & -1 & -1 & -1 & -1 & 84.31 & 7.94 \\
\hline
\end{tabular}


a

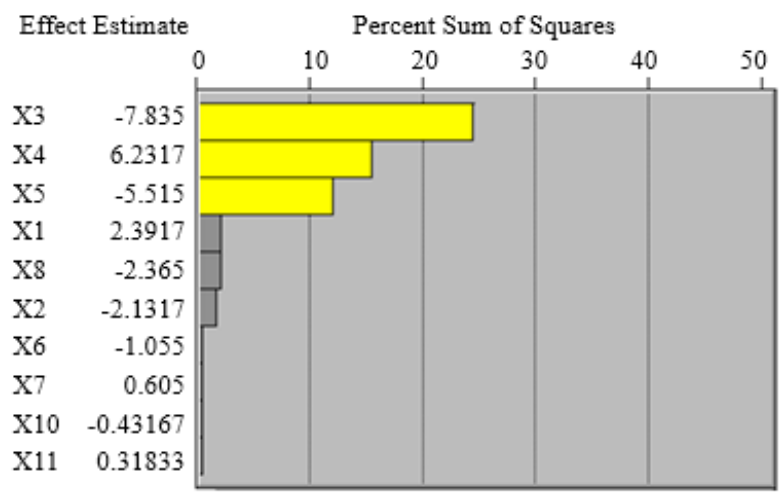

b

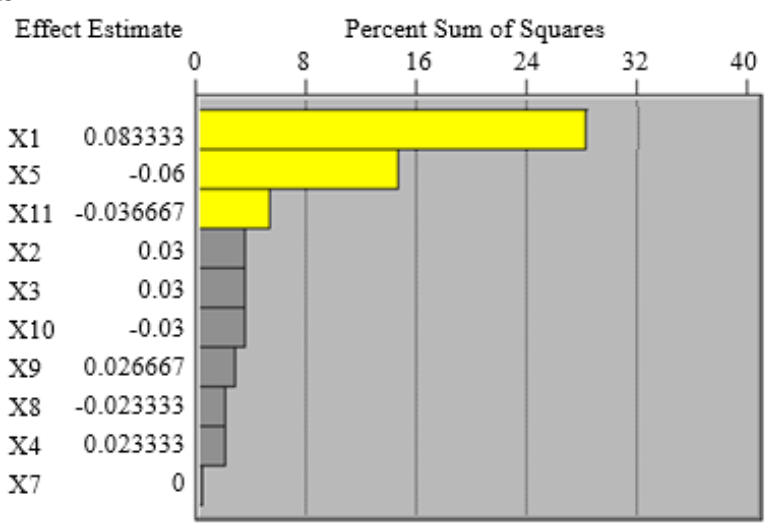

Fig. 3. The effects of factors on ACE inhibition rate (a) and viable counts of LB6 (b) for media of LB6

a

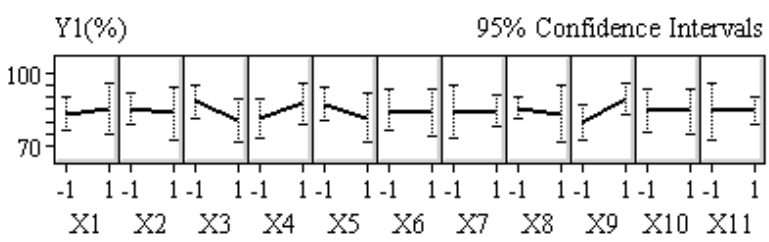

b

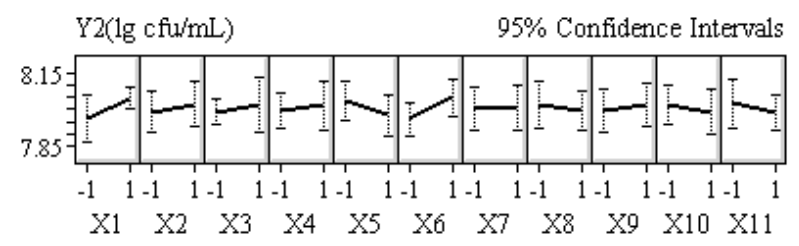

Fig. 4. The confidence interval of the selected factors of ACE inhibitory peptide-producing media regarding ACE inhibition rate (a) and viable counts of LB6 (b) factors affecting viable counts of LB6 in fermented goat's milk were casein peptone $(X 1)$, casein $(X 5)$ and $\mathrm{KH}_{2} \mathrm{PO}_{4}(X 11)$, in which the effect of casein peptone on viable counts of LB6 was positive and the effects of casein and $\mathrm{KH}_{2} \mathrm{PO}_{4}$ were negative (Fig. 4). According to the results of the Plackett-Burman test and principal factor analysis, soybean peptone, glucose and casein were further approximated to the corresponding response levels by the climbing test.

\section{DISCUSSION}

Temperature was reported to have a significant impact on the growth of $L$. bulgaricus LB6 and the activity of proteolytic enzyme. L. bulgaricus LB6 showed extremely poor growth with weak metabolic activity when the temperature was low, which resulted in low ACE inhibition rate and viable counts of LB6. With an increase in temperature, L. bulgaricus grew quickly and enzyme activity increased gradually. Therefore, the activity of LB6 and the ACE inhibition rate were enhanced. Increasing temperature could negatively impact the activity of proteolytic enzyme after reaching the optimum temperature. This caused a gradual decrease in ACE inhibition rate.

The viable counts of LB6 and ACE inhibition rate in fermented goat's milk first increased and then decreased as the concentration of whey powder increased. Therefore, whey powder has been used to increase the production of ACE inhibitory peptides. But the ACE inhibition rate gradually lessened in cow's milk fermented by $L$. casei with increasing concentrations of whey powder (Jiang et al., 2011), which may be due to the fact that the structure and content of whey protein in bovine and goat's milk are different. The addition of calcium lactate could promote growth of $L$. bulgaricus LB6, but inhibit the production of ACE inhibitory peptides in high concentrations. This probably could be due to the fact that ACE inhibitory peptides were produced and absorbed by the L. bulgaricus cell as a nutrient at the same time, which resulted in a decline in ACE inhibitory activity. The effects of ionic calcium on L. casei and Bifidobacterium bifidum were studied by Gonzalez-Gonzalez et al. (2011). The results indicated that ACE inhibitory peptides had a higher yield with the calcium added, which may be related to the effect of the ionic calcium channel. 
The addition of soybean peptone could promote the growth of L. bulgaricus LB6. Liu (2003) found that the addition of soybean peptone can promote the growth of Lactobacillus plantarum and Lactobacillus fermentum significantly, which was consistent with the results of this study. The reasons for this trend may be that soy peptone added at low concentrations elevated the total protein content in goat's milk and can be hydrolyzed into ACE inhibitory peptides. Therefore, the ACE inhibition rate was enhanced in a certain range. When soybean peptone concentration was increased further, the ACE inhibitory activity decreased, which may be due to excessive incomplete enzymatic hydrolysis of protein.

Casein is the main source of active peptides in fermented milk (Miguel et al., 2009). Added casein increased the amount of substrate in goat's milk. The ACE inhibitory activity was significantly improved by adding casein into goat's milk fermented by Lactobacillus plantarum L69 (Chen et al., 2013). ACE inhibitory activity was promoted by the increasing concentration of casein when goat's milk was fermented by $L$. bulgaricus LB6. Once the concentration reached the optimal value, the feedback effect may lead to a decline in ACE inhibitory peptide production.

As a monosaccharide, glucose can be absorbed directly by L. bulgaricus LB6 and then come into the glycolytic pathway for metabolic utilization. Thus, a positive impact of glucose concentration on the cell metabolism emerged in low concentrations of glucose. It is conducive to hydrolyzing the protein to produce more ACE inhibitory peptides. However, glucose in high concentrations can result in an increase in cell osmotic pressure and will inhibit the growth of L. bulgaricus LB6 in goat's milk, which causes a reduction in ACE inhibitory activity.

\section{CONCLUSION}

In this study, inoculum size, incubation temperature, goat's milk powder, sterilization time, whey powder, casein hydrolyses and calcium lactate were investigated to optimize ACE inhibitory peptide-producing conditions for L. bulgaricus LB6. Meanwhile, casein peptone, soybean peptone, glucose, casein, ascorbic acid, $\mathrm{Ca}\left(\mathrm{H}_{2} \mathrm{PO}_{4}\right)_{2}$ and lactose were examined to optimize ACE inhibitory peptide-producing media.
Investigation of $\mathrm{ACE}$ inhibitory peptide-producing conditions and media for LB6 was performed using a Plackett-Burman design and the results indicated that incubation temperature, whey powder, calcium lactate, soybean peptone, glucose and casein had significant effects on both ACE inhibition rate and viable counts of LB6. These results provide the basis and reference for further optimization.

\section{REFERENCE}

Abassi, Z., Winaver, J., Feuerstein, G. Z. (2009). The biochemical pharmacology of renin inhibitors: implications for translational medicine in hypertension, diabetic nephropathy and heart failure: expectations and reality. Biochem. Pharmacol., 78, 933-940. https://doi. org/10.1016/j.bcp.2009.05.018

Belewu, M. A., Aiyegbusi, O. F. (2002). Comparison of the mineral content and apparent biological value of milk from human, cow and goat. J. Food Tech. Afr. 7, 9-11. https://doi.org/10.4314/jfta.v7i1.19310

Chen, H., Ji, Z., Shu, G. W., Xing, H. N. (2012). Effect of probiotic lactobacillus strains on angiotensin I converting enzyme inhibitory activity from fermented goat's milk. Adv. Mater. Res., 531, 442-445. https://doi. org/10.4028/www.scientific.net/AMR.531.442

Chen, H., Zhang, Q. H., Tian, Y., Wang, J., Shu, G. W. (2013). Effect of carbon and nitrogen sources on production of ACE inhibitory peptides fermented by Lactobacillus plantarum L69 from goat's milk. J. Shaanxi Univ. Sci. Technol., 6, 105-108.

Cushman, D. W., Cheung, H. S. (1971). Spectrophotometric assay and properties of the angiotensin-converting-enzyme of rabbit lung. Biochem. Pharmacol., 20, 16371638. http://dx.doi.org/10.1016/0006-2952(71)90292-9

Duprez, D., Helshoecht, P. V., Eynde, W. V., Leeman, M. (2002). Prevalance of hypertension in the adult population of Belgium: report of a worksite study, Attention Hypertension. J. Hum. Hypertens., 16, 47-52. https:// doi.org/10.1038/sj.jhh.1001293

Gonzalez-Gonzalez, C. R., Tuohy, K. M., Jauregi, P. (2011). Production of angiotensin-I-converting enzyme (ACE) inhibitory activity in milk fermented with probiotic strains: effects of calcium, $\mathrm{pH}$ and peptides on the ACE-inhibitory activity. Int. Dairy J., 21(9), 615-622. https:// doi.org/10.1016/j.idairyj.2011.04.001

Grandi, A. M., Gaudio, G., Fachinetti, A., Bianchi, L., Nardo, B., Zanzi, P., ..., Venco, A. (1996). Hyperinsulinemia, family history of hypertension, and essential 
Shi, X., He, Ch., Meng, J., Xin, N., Ji, Z. (2018). The application of the Plackett-Burman design in investigating ACE inhibitory peptide-producing conditions and media for Lactobacillus bulgaricus LB6. Acta Sci. Pol. Technol. Aliment., 17(2), 125-132. http:// dx.doi.org/10.17306/J.AFS.2018.0536

hypertension. Am. J. Hypertens., 9, 732-738. http:// dx.doi.org/10.1016/0895-7061(96)00095-7

Haenlein, G. F. W. (2004). Goat's milk in human nutrition. Small Rumin. Res., 51, 155-163. https://doi. org/10.1016/j.smallrumres.2003.08.010

Hernández-Ledesma, B., Recio, I., Ramos, M., Amigo, L. (2002). Preparation of ovine and caprine beta-lactoglobulin hydrolysates with ACE-inhibitory activity. Identification of active peptides from caprine beta-lactoglobulin hydrolysed with thermolysin. Int. Dairy J., 12, 805-812. https://doi.org/10.1016/S0958-6946(02)00080-8

James, P. A., Oparil, S., Carter, B. L., Cushman W. C., Dennison-Himmelfarb, C., Handler, J., ..., Ortiz, E. (2014). 2014 evidence-based guideline for the management of high blood pressure in adults. Jama, 311, 507-520. http://dx.doi.org/10.1001/jama.2013.284427

Jiang, Z. M., Gang, W. U., Huo, G. C., Tian, B. (2011). Study on external conditions of angiotensin converting enzyme inhibitory peptide derived from fermented milk. Sci. Tech. Food Ind., 32(4), 106-108.

Kumar, R., Chaudhary, K., Sharma, M., Nagpal, G., Chauhan, J. S., Singh, S..., Raghava, G. P. S. (2015). AHTPDB: A comprehensive platform for analysis and presentation of antihypertensive peptides. Nucleic Acids Res., 43, 956-962. https://doi.org/10.1093/nar/gku1141

Leclerc, P. L., Gauthier, S. F., Bachelardb, H., Santure, M., Roy, D. (2002). Antihypertensive activity of caseinenriched milk fermented by Lactobacillus helveticus. Int. Dairy J., 12, 995-1004. https://doi.org/10.1016/ S0958-6946(02)00125-5

Liu, Y. H. (2003). The preparation of Lactic acid bacteria powder starter. J. Huaihai Inst. Techn., 4, 59-62.

López-Aliaga, I., Díaz-Castro, J., Ma, J. M. A., Barrionuevo, M., Campos, M. S. (2010). A review of the nutritional and health aspects of goat's milk in cases of intestinal resection. Dairy Sci. Technol., 90, 611-622. https://doi. org/10.1051/dst/2010028

MacMahon, S., Peto, R., Collins, R., Godwin, J., Cutler, J., Sorlie, P., ..., Stamler, J. (1990). Blood pressure, stroke and coronary heart disease. Lancet, 335, 827-838. http:// dx.doi.org/10.1016/0140-6736(90)90878-9

Maruyama, S., Mitachi, H., Awaya, J., Kurono, M., Tomizuka N., Suzuki, H. (2006). Angiotensin-I-converting enzyme inhibitory activity of the c-terminal hexapeptide of as1-casein. Biosci. Biotech. Bioch., 51, 2557-2561. https://doi.org/10.1080/00021369.1987.10868415

Miguel, M., Contreras, M. M., Recio, I., Aleixandre, A. (2009). ACE-inhibitory and antihypertensive properties of a bovine casein hydrolysate. Food Chem., 112(1), 211-214
Nakamura, Y., Masuda, O., Takano, T. (1996). Decrease of tissue angiotensin I-converting enzyme activity upon feeding sour milk in spontaneous hypertensive rats. Biosci. Biotech. Bioch., 60, 488-489. https://doi. org/10.1271/bbb.60.488

Ondetti, M. A., Cushman, D. W. (1982). Enzymes of the renin-angiotensin system and their inhibitors. Annu. Rev. Biochem., 51, 283-308. https://doi.org/10.1146/annurev. bi.51.070182.001435

Ondetti, M. A., Rubin, B., Cushman, D. W. (1977). Design of specific inhibitors of angiotensin-converting enzyme: new class of orally active antihypertensive agents. Science, 196, 441-444. http://dx.doi.org/10.1126/science.191908

Park, Y. W., Juárez, M., Ramos, M., Haenlein, G. F. W. (2007). Physico-chemical characteristics of goat and sheep milk. Small Rumin. Res., 68, 88-113. https://doi. org/10.1016/j.smallrumres.2006.09.013

Parmar, H., Hati, S., Sakure, A. (2017) In vitro and in silico analysis of novel ACE-inhibitory bioactive peptides derived from fermented goat's milk. Int. J. Pept. Res. Ther., 3, 1-13. https://doi.org/10.1007/s10989-017-9630-4

Pihlanto-Leppala, A. (2001). Bioactive peptides derived from bovine whey proteins: opioid and ACE-inhibitory peptides. Trends Food Sci. Tech., 11, 347-356. https:// doi.org/10.1016/S0924-2244(01)00003-6

Shu, G., Yang, H., Chen, H., Ji, Z., Xing, H. (2013a). Effect of ascorbic acid, incubation temperature and inoculum size on ACE inhibitory activity in fermented goat's milk by Lactobacillus bulgaricus LB6. J. Chem. Pharm., 61(2), 152-158.

Shu, G., Yang, H., Chen, H., Ji, Z., Xing, H. (2013b). Effect of carbon source and salts on angiotensin-I-converting enzyme (ACE) inhibitory activity in fermented goat's milk by Lactobacillus bulgaricus LB6. J. Pure Appl. Microb., 7, 301-308.

Shu, G., Yang, H., Chen, H., Ji, Z., Xing, H. (2014). Effect of organic nitrogen source on angiotensin-I-converting enzyme (ACE) inhibitory peptides fermented by Lactobacillus bulgaricus LB6 from goat's milk. Adv. J. Food Sci. Tech., 6(2), 221-227.

Skeggs, L. T., Kahn, J. R., Shumway, N. P. (1956). The preparation and function of the hypertension-converting enzyme. J. Exp. Med., 103, 295-299. http://dx.doi. org/10.1084/jem.103.3.295

Tenenbaum, A., Grossman, E., Shemesh, J., Fisman, E. Z., Nosrati, I., Motro, M. (2000). Intermediate but not low doses of aspirin can suppress angiotensin-converting enzyme inhibitor-induced cough. Am. J. Hypertens., 13, 776-782. https://doi.org/10.1016/S0895-7061(00) 00268-5 